\title{
Critical role of $\beta 1$ integrin in postnatal beta-cell function and expansion
}

\author{
Jason Peart ${ }^{1,2}$, Jinming Li ${ }^{1,3}$, Hojun Lee ${ }^{1,3}$, Matthew Riopel ${ }^{1}$, Zhi-Chao Feng ${ }^{1}$ and \\ Rennian Wang ${ }^{1,3}$ \\ ${ }^{1}$ Children's Health Research Institute, London, Ontario, N6C 2V5, Canada \\ ${ }^{2}$ Department of Pathology, University of Western Ontario, London, Ontario, N6A 3K7, Canada \\ ${ }^{3}$ Department of Physiology and Pharmacology, University of Western Ontario, London, Ontario, N6A 3K7, Canada \\ Correspondence to: Rennian Wang, email: rwang@uwo.ca \\ Keywords: $\beta 1$ integrin, mouse insulin promoter (MIP), glucose tolerance test, Cre recombinase, beta-cell mass \\ Received: November 01, $2016 \quad$ Accepted: April 21, $2017 \quad$ Published: May 18, 2017 \\ Copyright: Peart et al. This is an open-access article distributed under the terms of the Creative Commons Attribution License 3.0 \\ (CC BY 3.0), which permits unrestricted use, distribution, and reproduction in any medium, provided the original author and source \\ are credited.
}

\section{ABSTRACT}

$\beta 1$ integrin is essential for pancreatic beta-cell development and maintenance in rodents and humans. However, the effects of a temporal beta-cell specific $\beta 1$ integrin knockout on adult islet function are unknown. We utilized a mouse insulin 1 promoter driven tamoxifen-inducible Cre-recombinase $\beta 1$ integrin knockout mouse model (MIP $\beta 1 K O$ ) to investigate $\beta 1$ integrin function in adult pancreatic beta-cells. Adult male MIPß1KO mice were significantly glucose intolerant due to impaired glucose-stimulated insulin secretion in vivo and ex vivo at 8 weeks post-tamoxifen. The expression of Insulin and Pancreatic and duodenal homeobox-1 mRNA was significantly reduced in MIP $\beta 1 K O$ islets, along with reductions in insulin exocytotic proteins. Morphological analyses demonstrated that beta-cell mass, islet density, and the number of large-sized islets was significantly reduced in male MIP $\beta 1 \mathrm{KO}$ mice. Significant reductions in the phosphorylation of signaling molecules focal adhesion kinase, extracellular signal-regulated kinases 1 and 2, and v-Akt murine thymoma viral oncogene were observed in male MIP $\beta 1 K O$ islets when compared to controls. MIP $\beta 1 K O$ islets displayed a significant increase in protein levels of the apoptotic marker cleaved-Poly (ADP-ribose) polymerase and a reduction of the cell cycle marker cyclin D1. Female MIPB1KO mice did not develop glucose intolerance or reduced beta-cell mass until 16 weeks post-tamoxifen. Glucose intolerance remained in both genders of aged MIP $\beta 1 K O$ mice. This data demonstrates that $\beta 1$ integrin is required for the maintenance of glucose homeostasis through postnatal beta-cell function and expansion.

\section{INTRODUCTION}

Integrins are important regulators of cellular differentiation, migration, maturation, and survival [1-3]. $\beta 1$ integrin is the major $\beta$ integrin subunit in pancreatic betacells and forms heterodimers with $12 \alpha$ integrin subunits, which interact with components of the extracellular matrix $(\mathrm{ECM})$ to control intracellular signaling via the focal adhesion kinase (FAK) and extracellular signal related kinase 1 and 2 (ERK1/2) pathways [4]. The role of $\beta 1$ integrin in maintaining optimal islet function has previously been identified in vitro using cell lines and isolated islets. Cultured rat [5-8] and human $[4,9-11]$ islets have shown that inhibition of $\beta 1$ integrin reduced insulin secretion $[8,10]$ and islet adhesion to ECM [4-7, 10-12], while increasing apoptosis $[4,8-10]$. 
The conditional CreER-loxP deletion of $\beta 1$ integrin in adult murine collagen I-producing cells $(\beta 1 \mathrm{KO})$, one of the major ECM proteins in islets [13], demonstrated impaired glucose tolerance, decreased beta-cell mass and pancreatic and duodenal homeobox-1 (Pdx-1) expression, and a significant reduction in the phosphorylation of FAK and ERK1/2 signaling pathways [14]. Recently, a study using the rat insulin 2 promoter Cre-loxP system (RIP-Cre) to induce a beta-cell specific knockout of $\beta 1$ integrin $(\mathrm{RIP} \beta 1 \mathrm{KO})$ found that $\beta 1$ integrin is essential for maintaining beta-cell mass, but not function, during development and into adulthood [15]. However, the role of $\beta 1$ integrin on beta-cell function and survival in a tightly regulated age-dependent manner has yet to be determined. Here, we utilize CreERT-loxP technology to generate a mouse model that uses the mouse insulin 1 promoter (MIP) for the conditional knockout of beta-cell specific $\beta 1$ integrin (MIP $\beta 1 \mathrm{KO}$ ), allowing us to determine the role of $\beta 1$ integrin with respect to postnatal pancreatic beta-cell function and survival.

\section{RESULTS}

\section{Characterization of $\beta 1$ integrin expression in beta-cells of MIPß1KO mice}

The level of $\beta 1$ integrin knockdown in MIP $\beta 1 \mathrm{KO}$ mouse islets was quantified. We observed that $\beta 1$ integrin was significantly reduced at the mRNA and protein level $(\mathrm{p}<0.01$ vs. control, Figure 1A-1B) by approximately $60 \%$ in male MIP $\beta 1 \mathrm{KO}$ islets compared to controls at 8 weeks post-tamoxifen. Immunofluorescence staining confirmed a significant reduction of $\beta 1$ integrin $(\sim 45 \%)$ in the beta-cells of MIP $\beta 1 \mathrm{KO}$ mice compared to control mice $(p<0.001$ vs. control, Figure 1C-1D).

\section{MIPß1KO mice display impaired glucose tolerance}

Although no changes in fasting blood glucose were found in male MIP $\beta 1 \mathrm{KO}$ mice 8 weeks post-tamoxifen (Figure 2A), 16 weeks post-tamoxifen female MIP $\beta 1 \mathrm{KO}$ mice had significantly elevated fasting blood glucose levels compared to control littermates $(p<0.05$, Figure 2B). Body weight was unchanged in both male and female MIP $\beta 1 \mathrm{KO}$ mice when compared to their samesex littermates (data not shown). Male MIP $\beta 1 \mathrm{KO}$ mice 8 weeks post-tamoxifen displayed impaired glucose tolerance as determined by an intraperitoneal glucose tolerance test (IPGTT) $(\mathrm{p}<0.05$ vs. control, Figure $2 \mathrm{C})$. Significantly impaired glucose tolerance was not observed in female MIP $\beta 1 \mathrm{KO}$ mice until 16 weeks posttamoxifen injection $(\mathrm{p}<0.05$, Figure 2D). Intraperitoneal insulin tolerance tests (IPITT) revealed that both sexes of MIP $\beta 1 \mathrm{KO}$ and control mice responded in a similar fashion at all time points (Figure 2E-2F).

\section{Deficient glucose-stimulated insulin secretion in male, but not female, MIPß1KO mice}

Glucose-stimulated insulin secretion (GSIS) was measured in vivo and ex vivo to determine beta-cell functional responsiveness. In vivo GSIS results from male MIP $\beta 1 \mathrm{KO}$ mice demonstrated lower levels of plasma insulin at 5 and 35 minutes post glucose injection when compared to littermate controls $(\mathrm{p}<0.05$, Figure $3 \mathrm{~A})$. Basal insulin secretion from isolated male MIP $\beta 1 \mathrm{KO}$ islets was reduced by $\sim 50 \%$ compared to control islets $(\mathrm{p}<0.001$, Figure $3 \mathrm{C})$, and ex vivo GSIS displayed reduced insulin secretion from male MIP $\beta 1 \mathrm{KO}$ islets in response to glucose challenge $(p<0.05$, Figure $3 E)$. Despite the impairment in glucose tolerance at 16 weeks posttamoxifen, in vivo GSIS results from female MIP $\beta 1 \mathrm{KO}$ mice showed similar levels of plasma insulin as controls (Figure 3B). Basal insulin secretion from isolated female MIP $\beta 1 \mathrm{KO}$ islets was also unchanged (Figure 3D), and no significant reduction in insulin secretion was observed in ex vivo GSIS islets (Figure 3F). Islet insulin content of both male and female MIP $\beta 1 \mathrm{KO}$ mice were reduced compared to control littermates (Figure 3G-3H), but statistical significance was not reached.

\section{Reduction of insulin secretory molecules in MIPß1KO mice}

To determine whether impaired GSIS is due to a defect in the exocytosis of insulin granules from beta-cells, the exocytotic proteins involved in SNARE (Soluble N-Ethylmaleimide Sensitive-Factor Attachment Protein Receptor) complex formation were examined. A significant reduction in synaptosome associated protein $25 \mathrm{kDa}$ (Snap 25) and vesicle-associated membrane protein 2 (Vamp2) $(\mathrm{p}<0.05)$ mRNA, with relatively low levels of syntaxin 1a (Stx1a) and syntaxin 3 (Stx3) mRNA, was observed in male MIP $\beta 1 \mathrm{KO}$ mice compared to controls (Figure 4A). Immunofluorescence staining showed a clear reduction in beta-cell Snap25 and Vamp2 protein levels, in alignment with the reduction in mRNA observed in male MIP $\beta 1 \mathrm{KO}$ mice (Figure 4C). Mammalian uncoordinated-18 (Munc18-1) was also diminished in the beta-cells of male MIP $\beta 1 \mathrm{KO}$ mice with no change in syntaxin 1a staining (Figure 4D). Female MIP $\beta 1 \mathrm{KO}$ mice displayed a similar trend with reduced Snap25, Vamp2, Stx $1 a$ and Stx 3 mRNA, but the results were not statistically significant compared to controls (Figure 4B).

\section{Reduced Pdx-1 levels in male, but not female, MIPß1KO mice}

$\mathrm{Pdx}-1$ is an important regulator of insulin secretion [16], and both mRNA and protein levels were significantly reduced in the previously reported $\beta 1 \mathrm{KO}$ model [14]. Male MIP $\beta 1 \mathrm{KO}$ mice display 
a $40 \%$ reduction of $P d x-1$ mRNA in islets when compared to control mice ( $\mathrm{p}<0.01$, Figure 5A), along with a significant reduction in $\mathrm{Pdx}-1$ protein level as measured by western blot $(\mathrm{p}<0.01$, Figure $5 \mathrm{~B})$. Immunofluorescence staining for $\mathrm{Pdx}-1$ in beta-cells of male MIP $\beta 1 \mathrm{KO}$ mice was consistently less intense

A

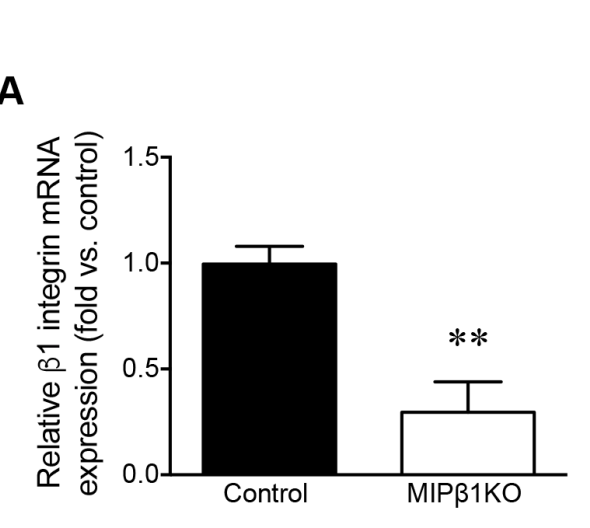

C

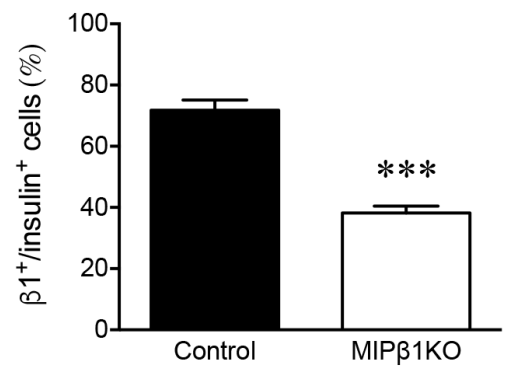

than in controls (Figure 5C). We further examined additional transcription factors involved in postnatal beta-cell regulation and function (NK6 homeobox 1 (Nkx6.1), NK2 homeobox 2 (Nkx2.2), Islet-1 (Isl-1), and $\mathrm{V}$-maf avian musculoaponeurotic fibrosarcoma homolog A (MafA)), and found similar staining
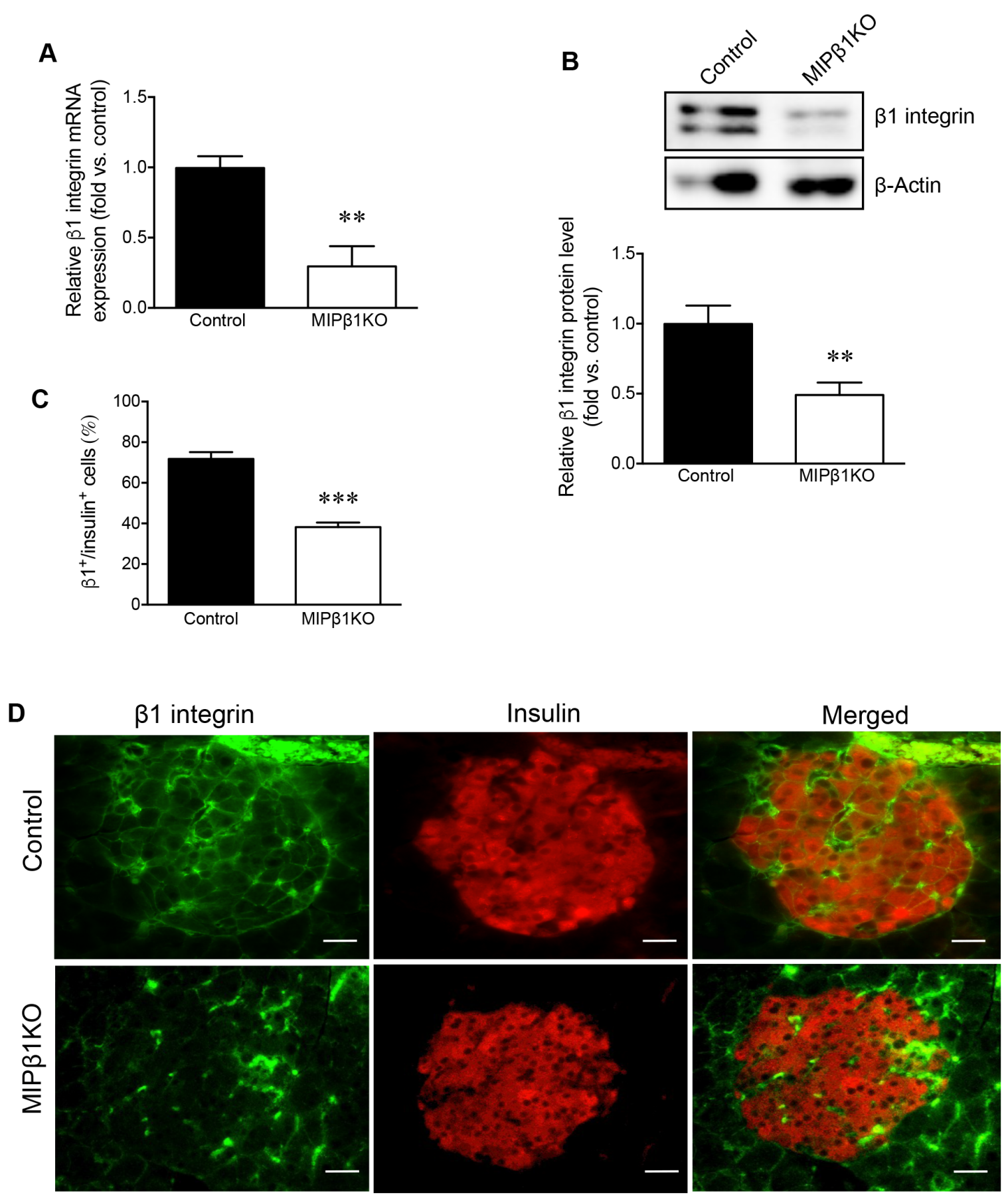

Figure 1: Confirmation of $\boldsymbol{\beta} 1$ integrin knockdown in MIPß1KO mouse islets. (A) qRT-PCR for $\beta 1$ integrin mRNA and (B) western blot analysis for $\beta 1$ integrin protein in male control and MIP $\beta 1 \mathrm{KO}$ islets after 8 weeks post-tamoxifen, with a representative blot shown. Quantification (C) and representative images (D) of $\beta 1$ integrin (green) and insulin (red) double immunofluorescence staining in the islets of control and MIP $\beta 1 \mathrm{KO}$ mice. Scale bar: $25 \mu \mathrm{m}$. Data are expressed as mean $\pm \operatorname{SEM}\left(n=3-5 /\right.$ group). ${ }^{* *} p<0.01 * * * p<0.001$ vs. control group. 
intensities between male MIP $\beta 1 \mathrm{KO}$ mice and control mice (Supplementary Figure 1). A significant reduction of Insulin, but not Glucagon, mRNA in male MIP $\beta 1 \mathrm{KO}$ mouse islets was also detected (Figure 5A). The mRNA levels of $P d x-1$, Insulin, and Glucagon in female MIP $\beta 1 \mathrm{KO}$ mouse islets were relatively lower than their control littermates, but did not reach statistical significance (Figure 5D).
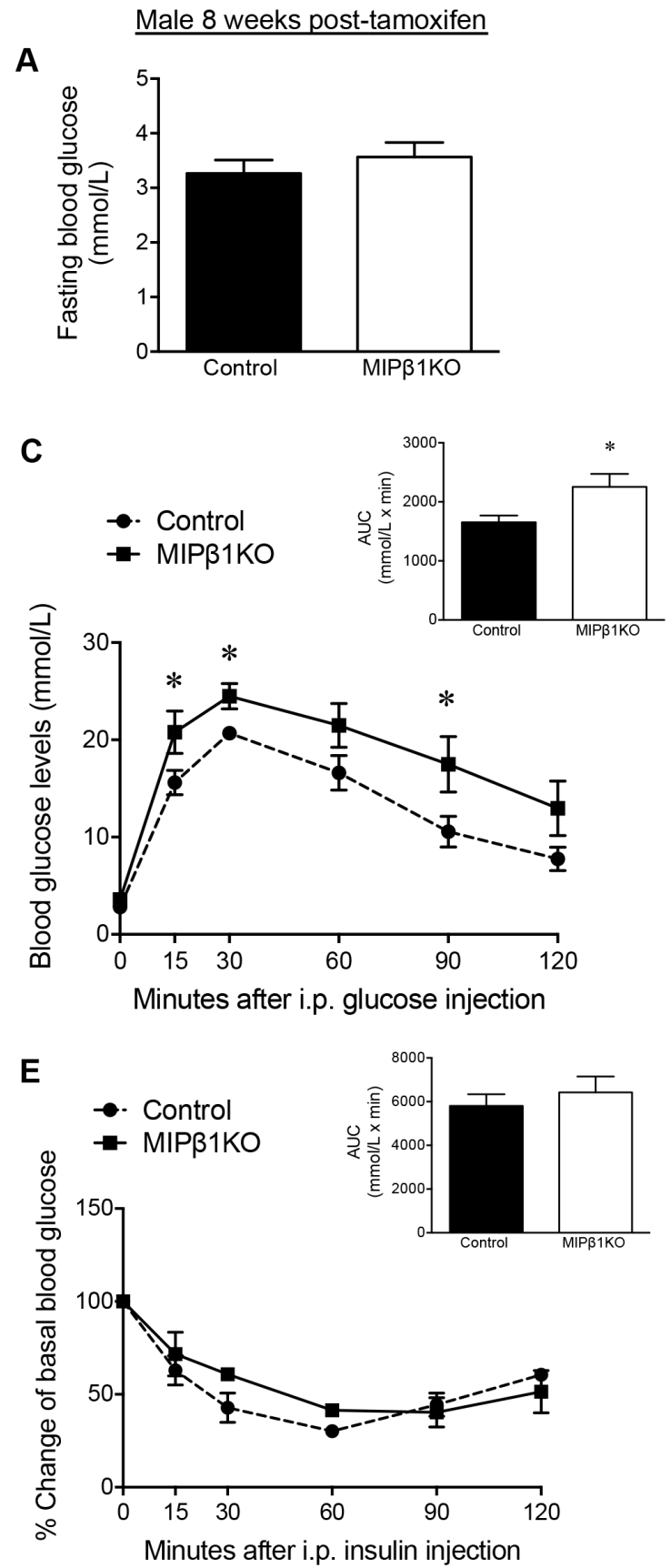

\section{Reduction of beta-cell mass in MIPß1KO mice, but no alteration in islet vasculature}

Immunofluorescence staining of $\mathrm{MIP} \beta 1 \mathrm{KO}$ and control pancreata showed that the overall architecture of the pancreas was unaltered, with intact islets and a normal distribution of insulin ${ }^{+}$and glucagon ${ }^{+}$cells observed (Figure 6A). Islet density (islets per $\mathrm{mm}^{2}$ ) was significantly reduced in male $\mathrm{MIP} \beta 1 \mathrm{KO}$ pancreata $(\mathrm{p}<0.05)$, while

\section{Female 16 weeks post-tamoxifen}

B

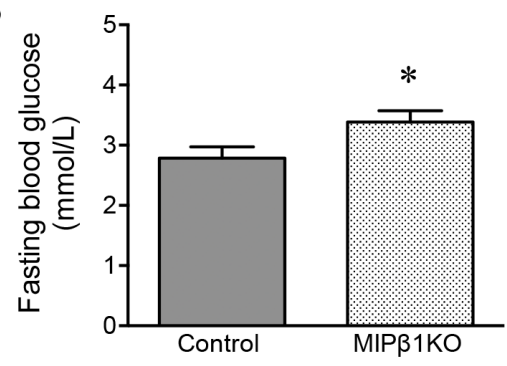

D

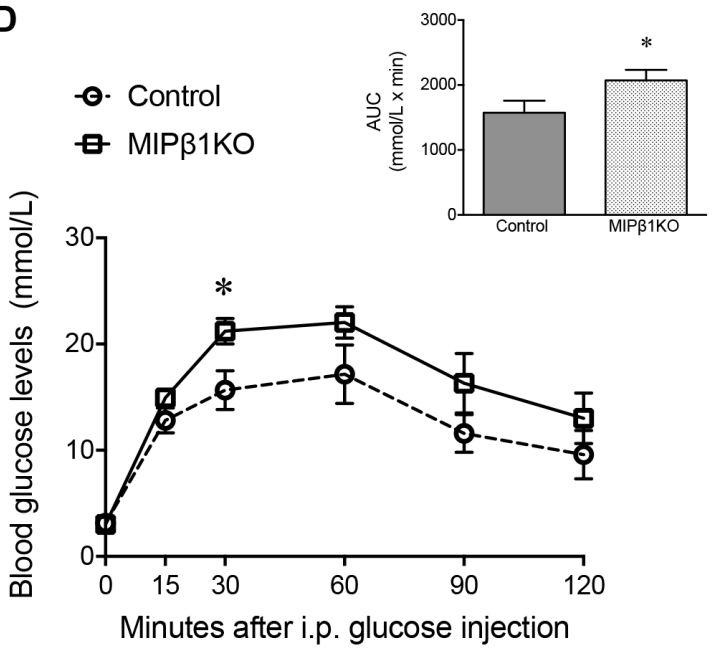

$\mathbf{F}$

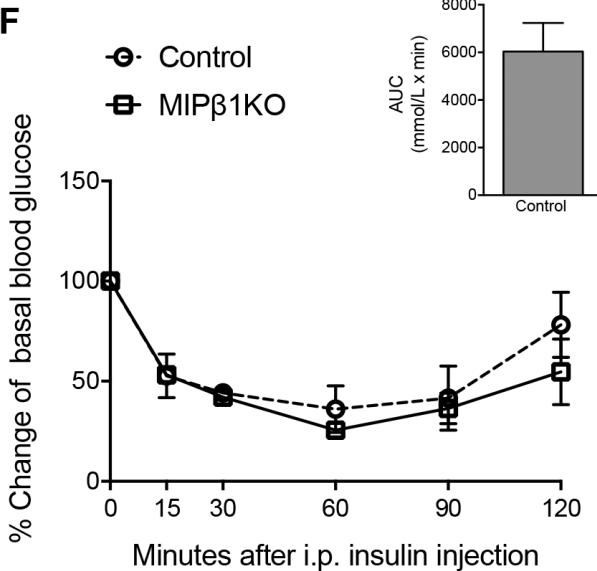

Figure 2: MIPß1KO mice show impaired glucose metabolism. Fasting blood glucose of control and MIP $\beta 1 \mathrm{KO}$ mice after 8 (male, A) or 16 (female, B) weeks post-tamoxifen. IPGTT $(\mathbf{C}, \mathbf{D})$ and IPITT $(\mathbf{E}, \mathbf{F})$ analyses, and their corresponding AUC, for control and MIP $\beta 1 \mathrm{KO}$ mice. Data are expressed as mean $\pm \operatorname{SEM}(n=3-8 /$ group $)$. ${ }^{*} p<0.05$ vs. control group. 
relatively lower islet density was observed in female MIP $\beta 1 \mathrm{KO}$ pancreata compared to the controls (Figure 6B). Male MIP $\beta 1 \mathrm{KO}$ mice demonstrated a significantly higher percentage of smaller islets $\left(<2,500 \mu \mathrm{m}^{2}\right)$ and a lower number of large islets $\left(<10,000 \mu \mathrm{m}^{2} ; \mathrm{p}<0.05\right.$, Figure 6C). Female MIP $\beta 1 \mathrm{KO}$ mice also showed a higher percentage of the smallest islets $\left(<500 \mu \mathrm{m}^{2}\right)$ and a low number of the largest islets $\left(>10,000 \mu \mathrm{m}^{2}\right)$ when compared to control mice $(p<0.05$, Figure $6 D)$. The decrease in larger islets was accompanied by significantly reduced beta-cell mass in both male and female MIP $\beta 1 \mathrm{KO}$ mice $(\mathrm{p}<0.05$, Figure $6 \mathrm{E}-6 \mathrm{~F})$. Reductions in alpha-cell mass were observed in female $(p<0.05$, Figure $6 \mathrm{H})$, but not male (Figure $6 \mathrm{G}$ ), MIP $\beta 1 \mathrm{KO}$ pancreata.

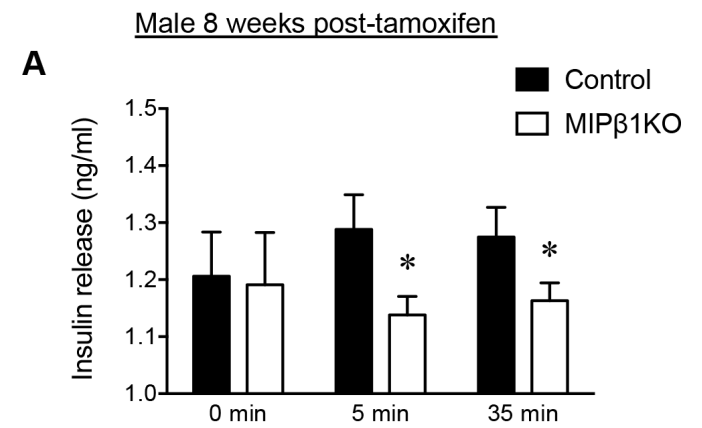

\section{Female 16 weeks post-tamoxifen}

B

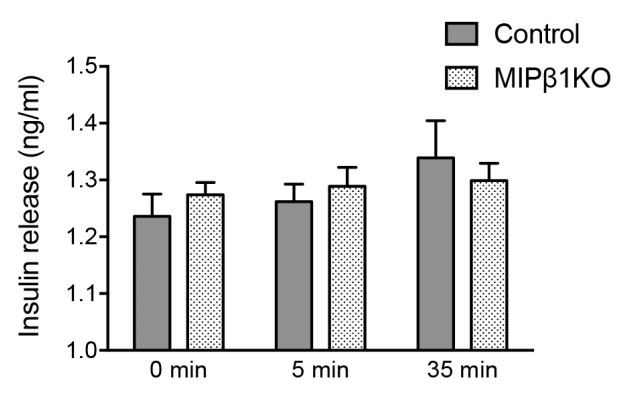

D
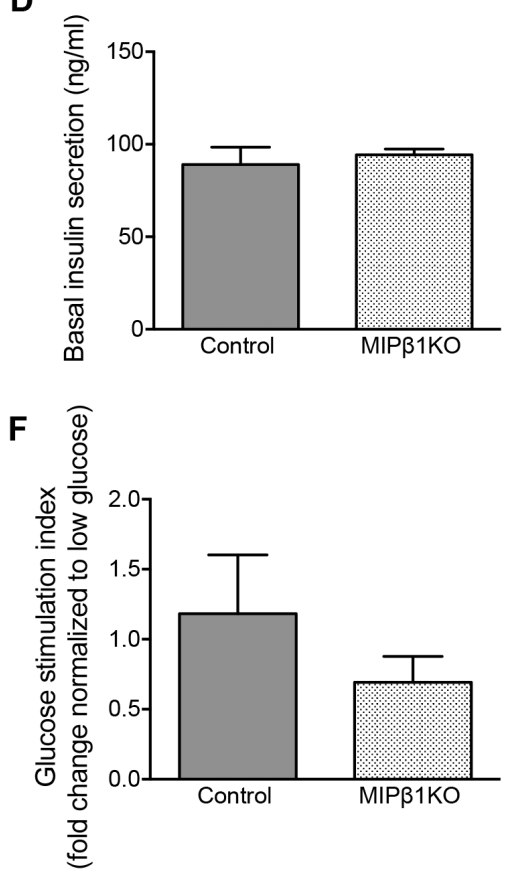

H

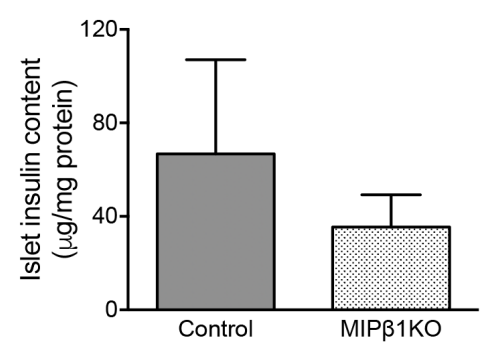

Figure 3: Impaired in vivo and ex vivo glucose-stimulated insulin secretion (GSIS) in male MIPß1KO mice. In vivo GSIS assay showing blood glucose and plasma insulin levels in male (A) and female (B) control and MIP $\beta 1 \mathrm{KO}$ mice 8 or 16 weeks posttamoxifen. Overnight basal insulin secretion from isolated islets of male (C) and female (D) control and MIP $\beta 1 \mathrm{KO}$ mice. (E, F) Ex vivo insulin secretion in response to high glucose conditions displayed as fold change normalized to low glucose (2.2mM) secretion. Islet insulin content in isolated islets from male $\mathbf{( G )}$ and female $\mathbf{( H )}$ control and MIP $\beta 1$ KO mice. Data are expressed as mean \pm SEM $(n=4-7 / g r o u p)$. ${ }^{*} p<0.05 ; * * * p<0.001$ vs. control group. 
Immunofluorescence staining for E-cadherin and Glut2, proteins required for the maintenance of betacell function, displayed no change in male or female MIP $\beta 1 \mathrm{KO}$ islets (Supplementary Figure 2). Additional integrin subunits were also examined within islets of male MIP $\beta 1 \mathrm{KO}$ mice. qRT-PCR analyses of $\alpha 6$ and $\alpha V$ integrin mRNA were relatively lower than that of controls, while $\alpha 3$ and $\alpha 5$ integrin mRNA were unchanged (Supplementary Figure 3A). Lower $\alpha 6$ and $\alpha \mathrm{V}$, but increased $\alpha 3$ integrin staining intensity was observed in male MIP $\beta 1 \mathrm{KO}$ islets compared to controls (Supplementary Figure 3B). In contrast, $\alpha 5$ integrin, which is predominantly expressed in alpha-cells, showed no change in staining intensity (Supplementary Figure 3B).
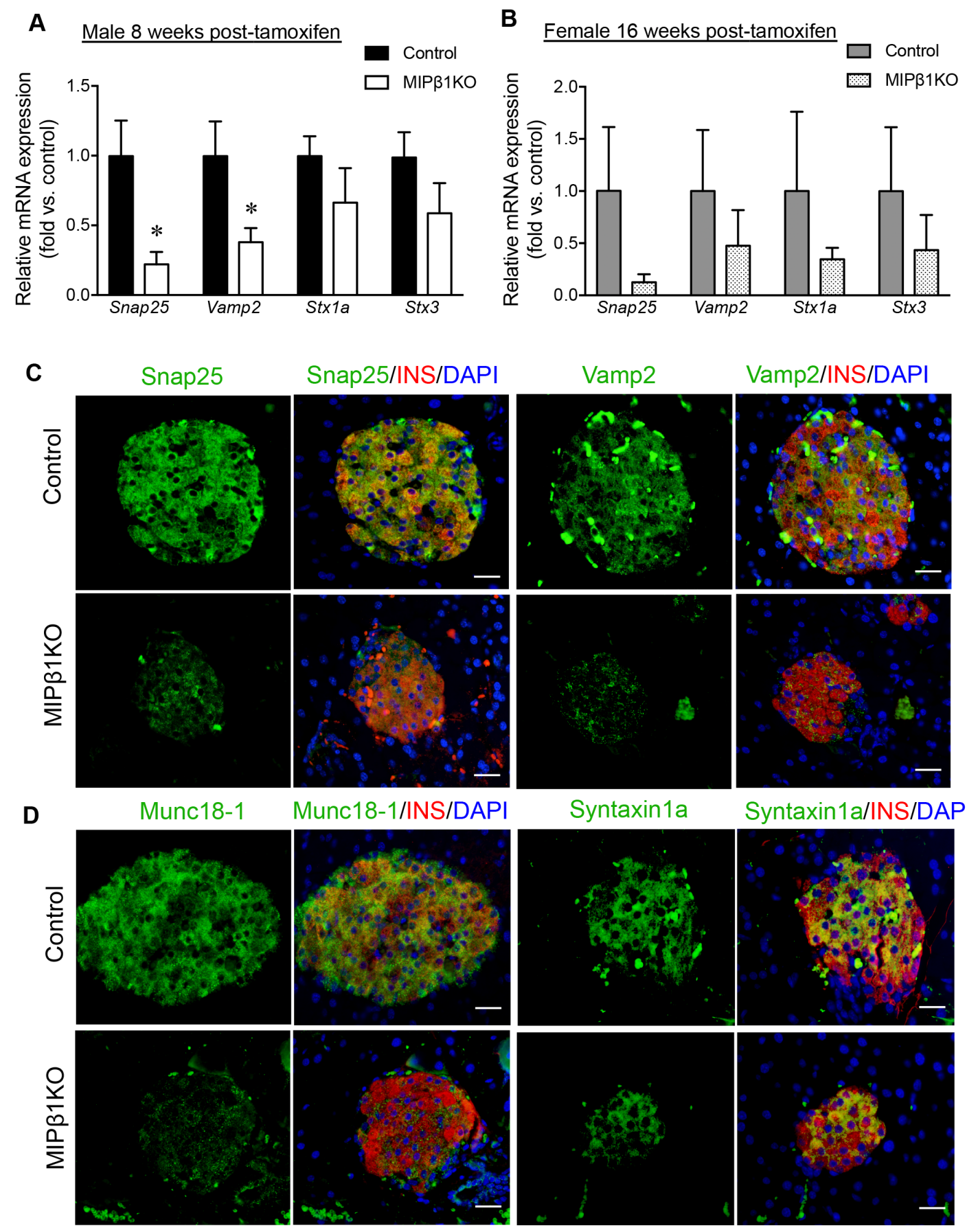

Syntaxin1a/INS/DAPI
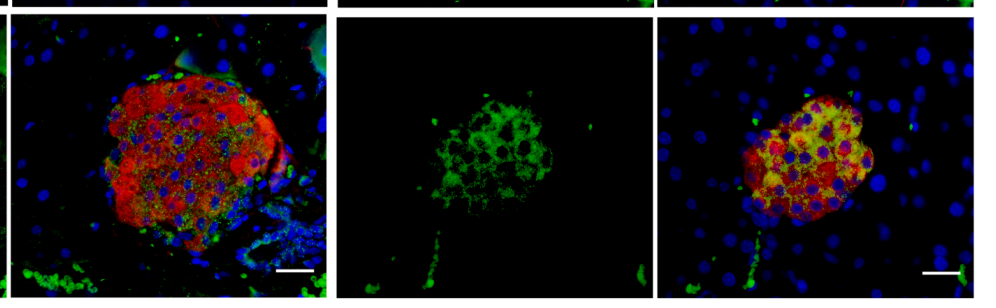

Figure 4: Reduced insulin exocytotic machinery in MIPß1KO mice. Relative mRNA expression of Snap25, Vamp2, Stx1a and Stx3 in male (A) and female (B) control and MIP $\beta 1 \mathrm{KO}$ mice 8 or 16 weeks post-tamoxifen. Data are expressed as mean $\pm \operatorname{SEM}(n=3-4 / g r o u p)$. ${ }^{*} p<0.05$ vs. control. (C, D) Representative immunofluorescence staining images for Snap25, Vamp2, Munc18-1 and Syntaxin1a (green) with insulin (red) in male control and MIP $\beta 1 \mathrm{KO}$ mice. Nuclei were labeled using DAPI (blue) $(n=3 /$ group). Scale bar: $25 \mu \mathrm{m}$. 
Although male $\beta 1 \mathrm{KO}$ mice had a significant reduction in islet capillary area [14], qualitative assessment of PECAM $^{+}$blood vessel area and diameter in MIP $\beta 1 \mathrm{KO}$ mouse islets showed no obvious alterations in either gender of MIP $\beta 1 \mathrm{KO}$ mouse islets at 8 (male) or 16 weeks (female) post-tamoxifen when compared to controls (Supplementary Figure 4).
Reduction of phosphorylated-FAK, ERK1/2, and Akt protein levels with reduced cell proliferation in male MIPß1KO mice

FAK, ERK1/2, and Akt are downstream signaling molecules of $\beta 1$ integrin that have been shown to regulate beta-cell proliferation, survival, and function [4, 12, $14,17]$. There was a significant reduction in $\mathrm{p}^{-F^{2}} \mathrm{KK}^{\mathrm{Y} 397}$

A Male 8 weeks post-tamoxifen injection

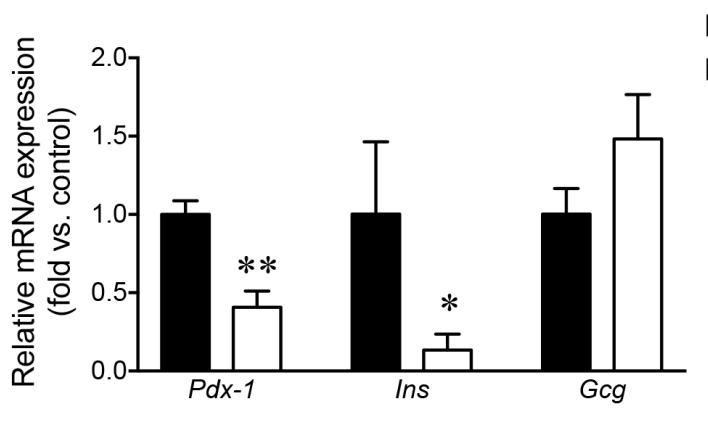

Control

MIPß1KO

B

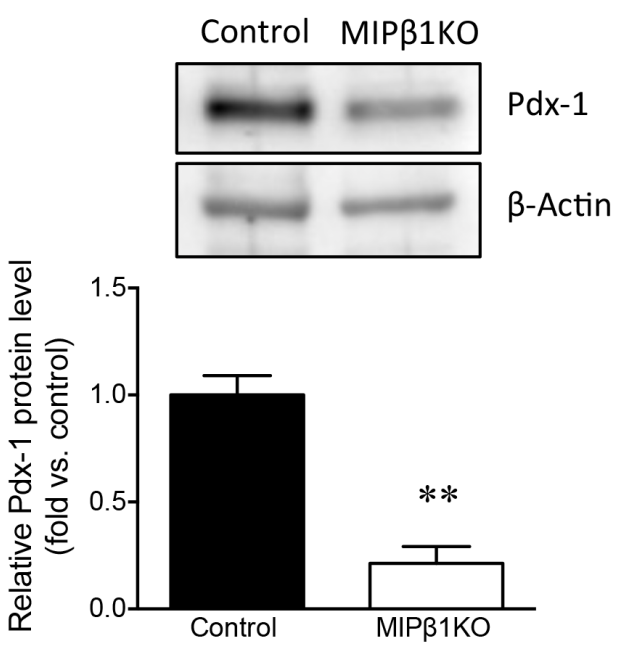

C

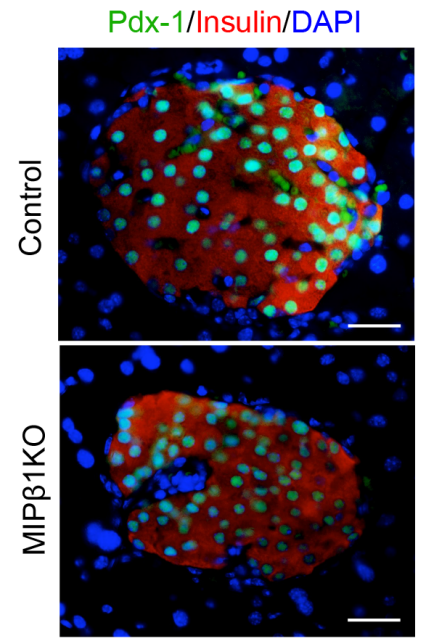

D Female 16 weeks post-tamoxifen injection

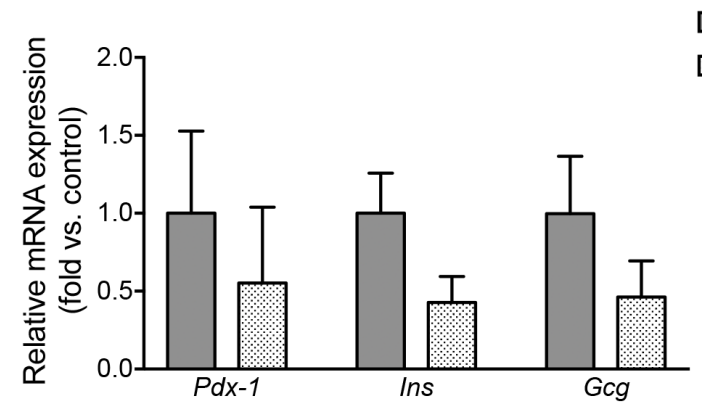

Figure 5: Decreased Pdx-1, insulin, and glucagon expression in MIPß1KO mice. (A) qRT-PCR analysis for $P d x-1, I n s$, and Gcg mRNA expression in male control and MIP $\beta 1 \mathrm{KO}$ mice 8 weeks post-tamoxifen. (B) Pdx-1 protein levels in male control and MIP $\beta 1 K O$ mouse islets, with representative blot shown. (C) Representative immunofluorescence images for Pdx-1 (green), insulin (red) and DAPI (blue) in male control and MIP $\beta 1 \mathrm{KO}$ mouse islets. Scale bar: $25 \mu \mathrm{m}$. (D) qRT-PCR analysis for Pdx-1, Ins, and Gcg mRNA expression of female control and MIP $\beta 1 \mathrm{KO}$ mice at 16 weeks post-tamoxifen. Data are expressed as mean $\pm \operatorname{SEM}(n=3-6 / g r o u p) . * p<0.05$, $* * p<0.01$ vs. control group. 
$(p<0.001$, Figure 7A) and $p$-ERK1/2 $(p<0.05$, Figure 7B) in male MIP $\beta 1 \mathrm{KO}$ mouse islets compared to controls. A significant decrease in $\mathrm{p}-\mathrm{Akt}^{\mathrm{S} 473}$ was also observed in male MIP $\beta 1 \mathrm{KO}$ islets $(\mathrm{p}<0.05$, Figure $7 \mathrm{C})$. Protein levels of the proliferative marker cyclin D1 were found to be significantly reduced in male MIP $\beta 1 \mathrm{KO}$ mouse islets compared to controls ( $\mathrm{p}<0.05$, Figure 7D), and a significant increase in the apoptotic marker cleaved-Poly (ADP-ribose) polymerase (c-PARP) was also evident in male MIP $\beta 1 \mathrm{KO}$ islets $(\mathrm{p}<0.05$, Figure $7 \mathrm{E})$. The percentage of $\mathrm{Ki}^{+} 7^{+}$beta-cells in male MIP $\beta 1 \mathrm{KO}$ islets was also relatively lower than that of controls (Figure 7F).
A
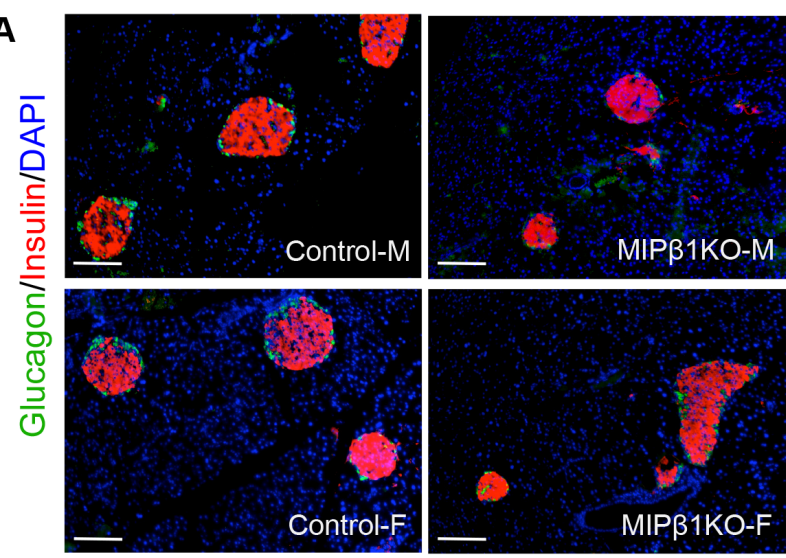

B
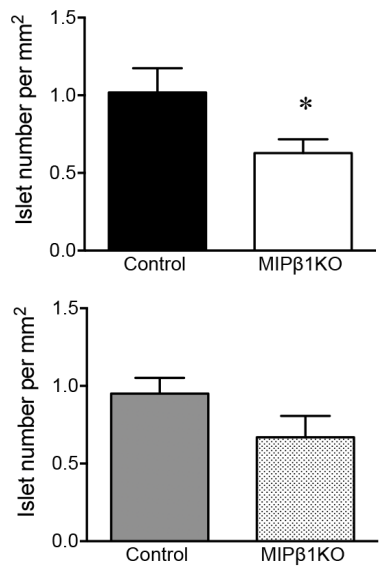

C

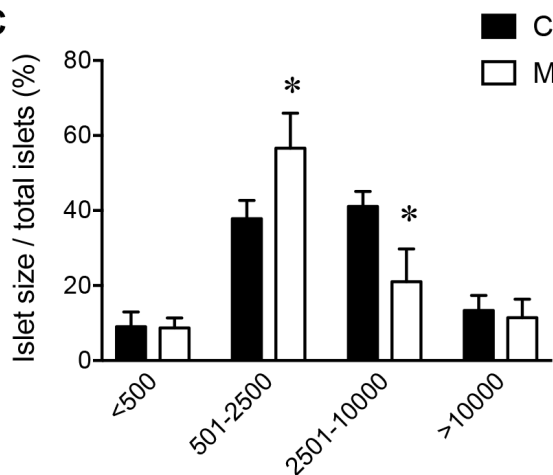

E

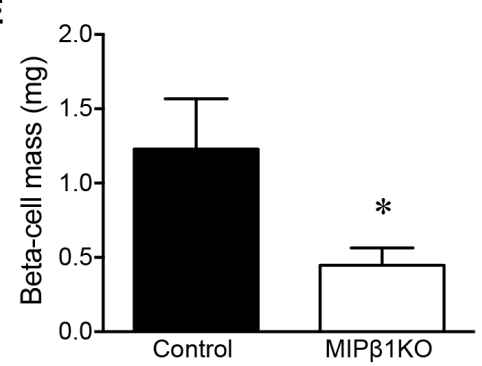

\section{G}

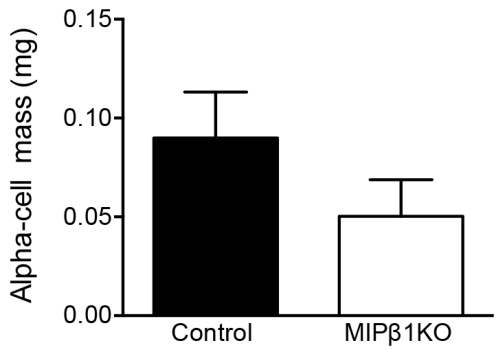

Control

MIP $\beta 1 \mathrm{KO}$

D

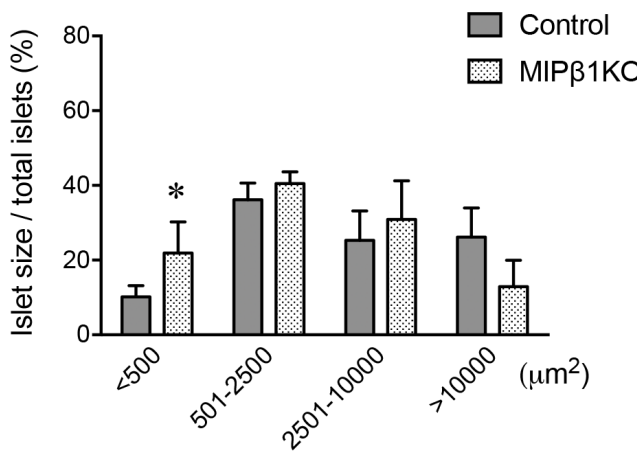

F

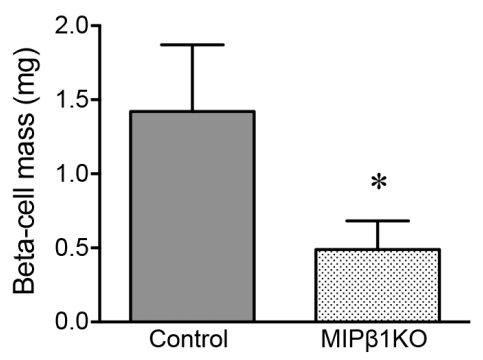

H

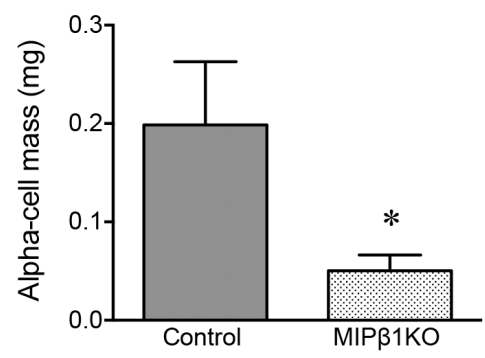

Figure 6: MIPß1KO mice display smaller islets with loss of beta-cell mass. (A) Representative immunofluorescence staining of glucagon (green) and insulin (red) to indicate islet labeling. Nuclei were stained with DAPI (blue) in both male and female control and MIP $\beta 1 \mathrm{KO}$ mice. Scale bar: $200 \mu \mathrm{m}$. Islet number (B), islet size (C, D), beta-cell mass (E, F) and alpha-cell mass (G, H) of control and MIP $\beta 1 \mathrm{KO}$ mice 8 or 16 weeks post-tamoxifen. Data are expressed as mean $\pm \operatorname{SEM}(n=5-6 /$ group $) .{ }^{*} p<0.05$ vs. control group. 


\section{Glucose intolerance was maintained in aged MIPß1KO mice}

To investigate whether MIP $\beta 1 \mathrm{KO}$ mice maintained long-term glucose intolerance, both male and female MIP $\beta 1 \mathrm{KO}$ mice were examined at 25-35 weeks posttamoxifen. The aged MIP $\beta 1 \mathrm{KO}$ mice maintained the reduction of $\beta 1$ integrin levels ( $40 \%$ loss) in betacells when compared to controls (Supplementary
Figure 5). Aged male MIP $\beta 1 \mathrm{KO}$ mice showed a significant elevation in overnight fasting blood glucose levels ( $<<0.05$, Figure 8A). Interestingly, aged female MIP $\beta 1 \mathrm{KO}$ mice also developed higher fasting blood glucose levels (Figure 8B). Similar body weight was observed in all aged groups (Figure 8C-8D). IPGTT in aged male MIP $\beta 1 \mathrm{KO}$ mice showed significantly elevated glucose levels at 60,90 , and 120 minutes after glucose injection $(\mathrm{p}<0.05-0.01$, Figure $8 \mathrm{E})$, and
A
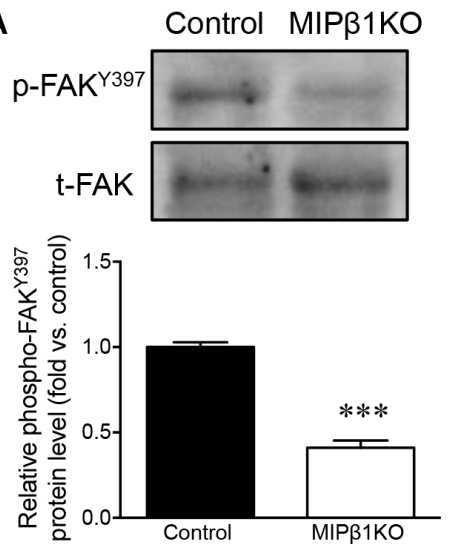

D
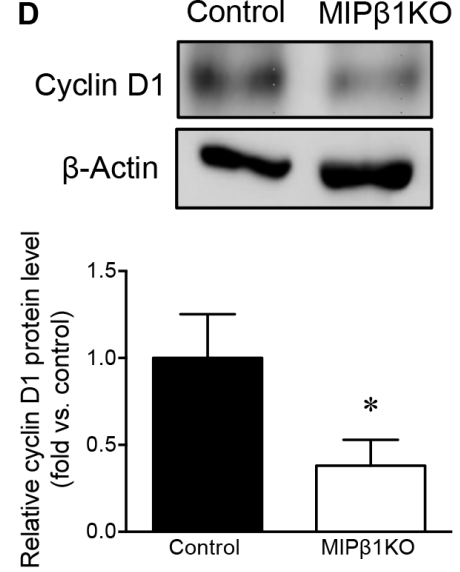
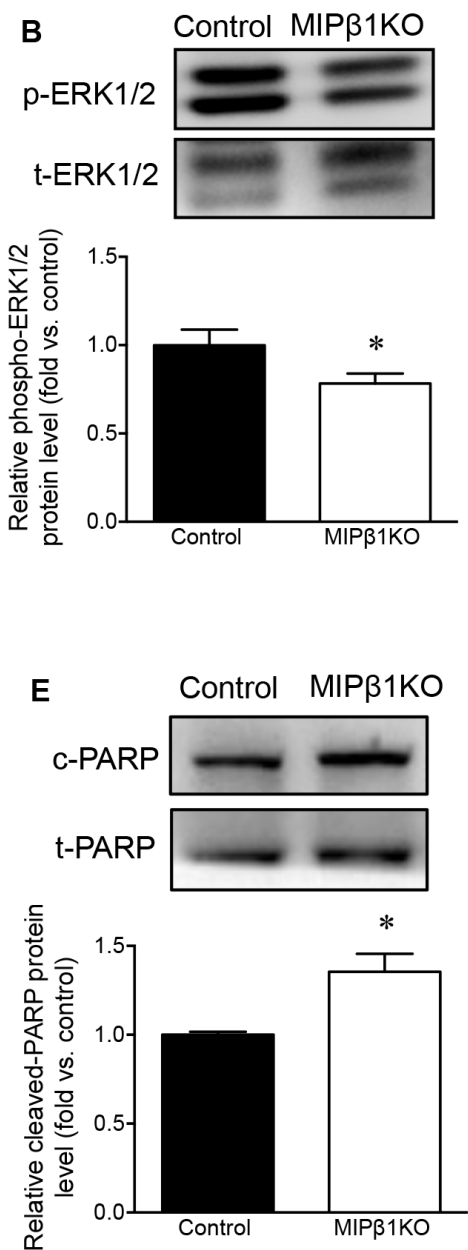

$\mathbf{F}$
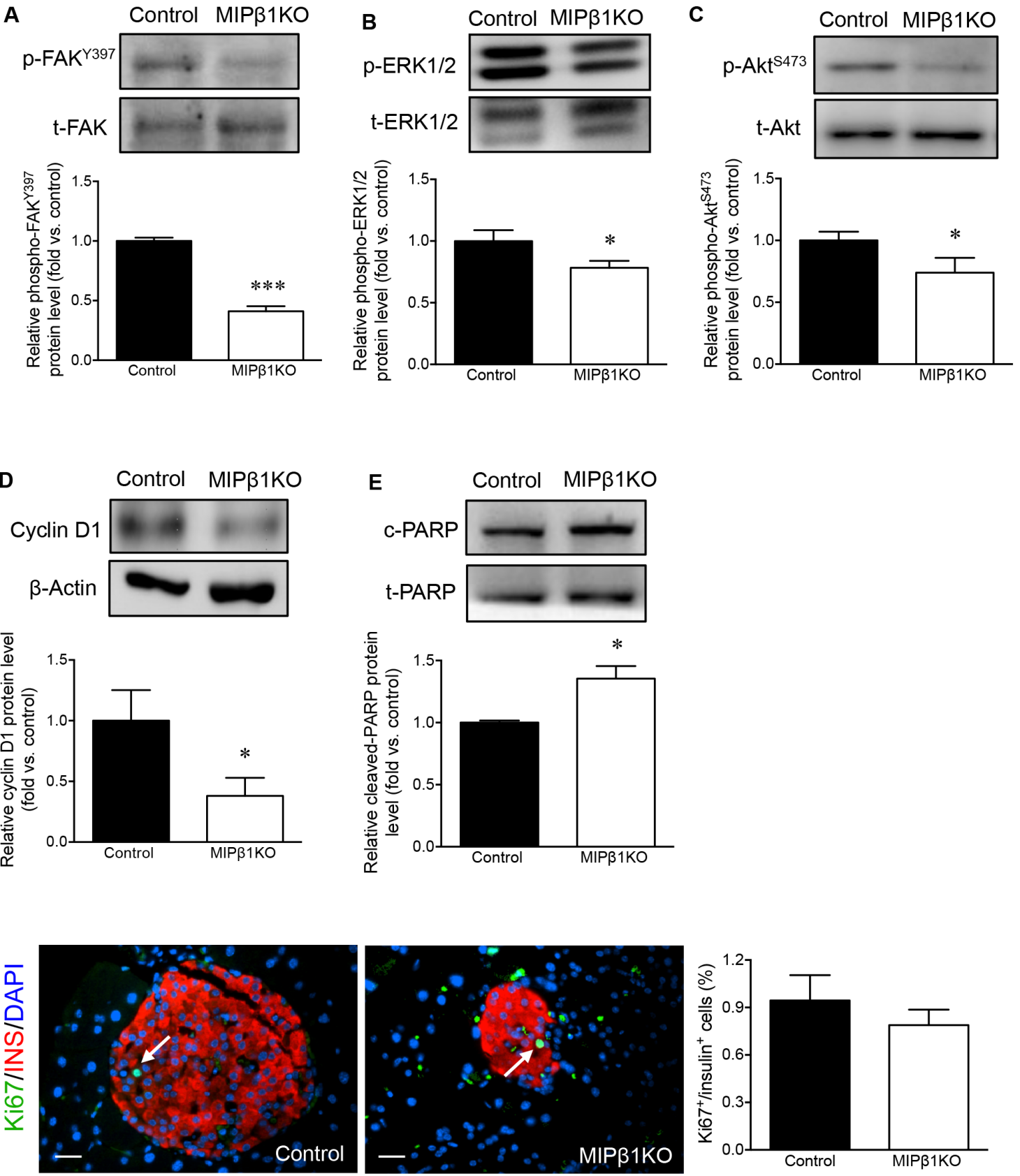

Figure 7: Altered intracellular cell signaling, proliferation, and apoptotic protein levels in male MIPß1KO mouse islets. Western blot analyses for p-FAK ${ }^{\mathrm{Y} 397}$ (A), pERK1/2 (B), p-Akt ${ }^{\mathrm{S} 73}$ (C), cyclin D1 (D) and c-PARP (E) protein levels with representative blots shown for male control and MIP $\beta 1 \mathrm{KO}$ mouse islets 8 weeks post-tamoxifen. (F) Representative immunofluorescence staining for Ki67 (green), insulin (red), and DAPI (blue in nuclei), and quantification of Ki67 beta-cells. White arrows indicate nuclear localization of Ki67 in insulin ${ }^{+}$cells. Scale bar: $25 \mu \mathrm{m}$. Data are expressed as mean $\pm \operatorname{SEM}(n=3-11 /$ group $) .{ }^{*} p<0.05,{ }^{* * *} p<0.001$ vs control. 
an overall increase in AUC when compared to control mice $(p<0.05$, Figure $8 G)$. Aged female MIP $\beta 1$ KO mice also demonstrated significantly increased glucose levels $(30,60,90$, and 120 minutes post glucose load $)(p<0.05$ 0.01 , Figure $8 \mathrm{~F})$ and AUC $(\mathrm{p}<0.01$, Figure $8 \mathrm{H})$ during an IPGTT.

A Male 25-30 weeks post-tamoxifen

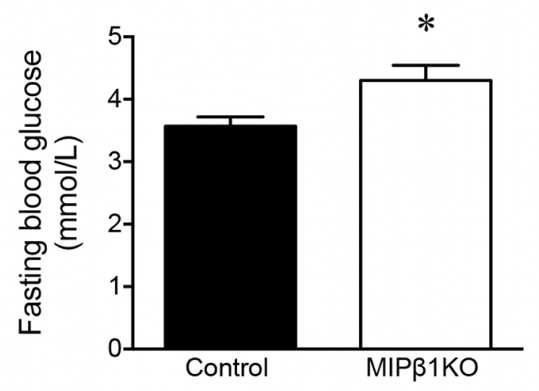

C

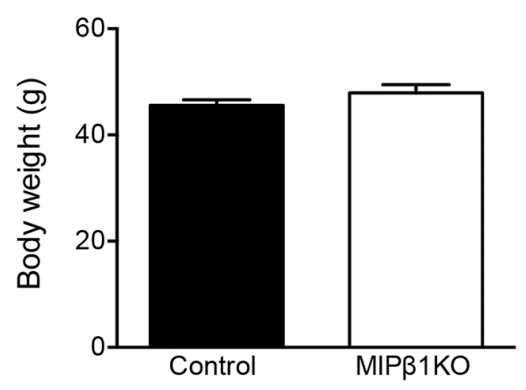

E

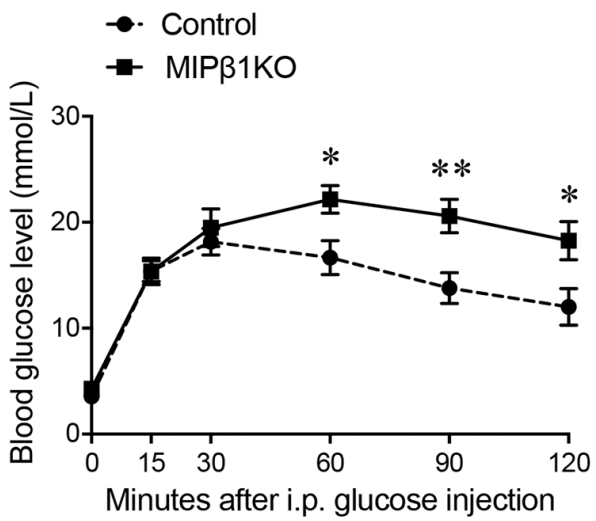

G

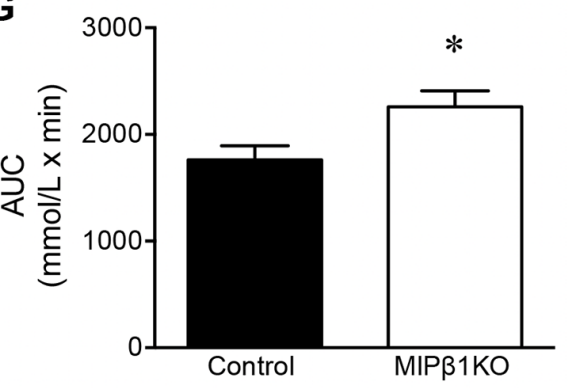

\section{DISCUSSION}

The inducible MIP $\beta 1 \mathrm{KO}$ mouse model allowed for in vivo evaluation of beta-cell-specific $\beta 1$ integrin activity during postnatal islet function. A significant reduction of beta-cell $\beta 1$ integrin expression in the adult mouse resulted

\section{B Female $30-35$ weeks post-tamoxifen}

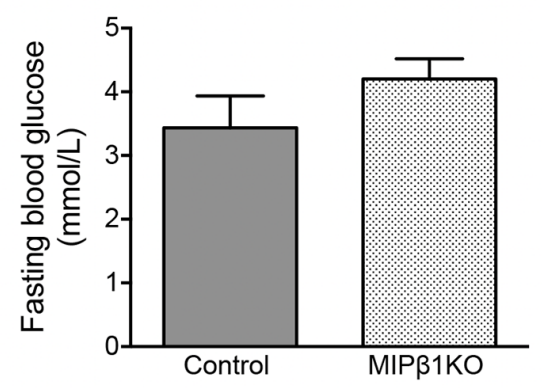

D

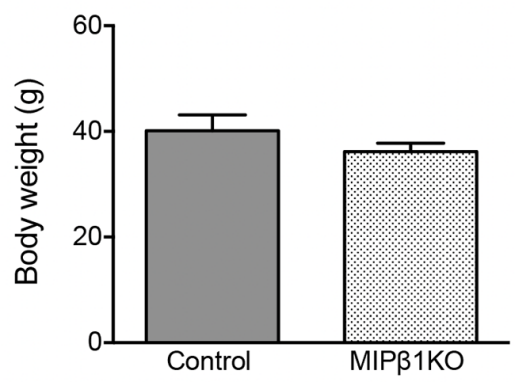

$\mathbf{F}$

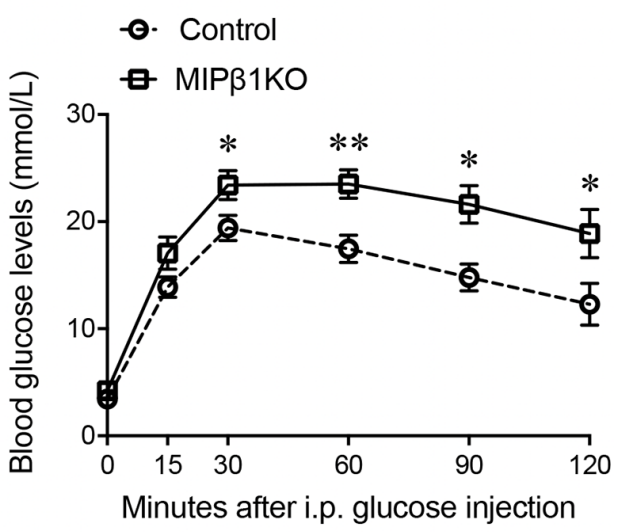

H

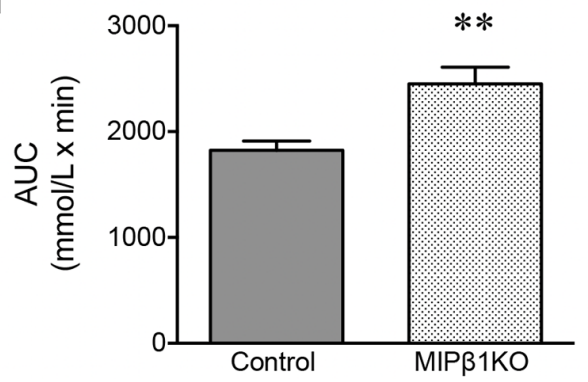

Figure 8: Impairment of glucose metabolism in aged MIPß1KO mice. Fasting blood glucose and body weight of aged male $(\mathbf{A}, \mathbf{C})$ and female (B, D) control and MIP $\beta 1$ KO mice. IPGTT analysis of aged control and MIP $\beta 1$ KO male (E) and female (F) mice, and corresponding $\operatorname{AUC}(\mathbf{G}, \mathbf{H})$. Data are expressed as mean $\pm \operatorname{SEM}(n=6-14 /$ group $)$. ${ }^{*} p<0.05, * * p<0.01$ vs. control. 
in impaired glucose tolerance and insulin secretion, reduced beta-cell mass, decreased signaling through the FAK/ERK and Akt pathways, and diminished beta-cell function and expansion. This study further demonstrates that $\beta 1$ integrin in adult pancreatic beta-cells is essential for maintaining normal beta-cell mass and insulin secretion.

In contrast to previous studies that utilized a global $\beta 1 \mathrm{KO}$ model $[14,18]$, there was no difference in pancreatic weight and macrostructure between MIP $\beta 1 \mathrm{KO}$ and control mice, indicating that the targeted loss of $\beta 1$ integrin in beta-cells does not compromise the architecture of the pancreas. The impaired glucose tolerance displayed in male MIP $\beta 1 \mathrm{KO}$ mice at 8 weeks post-tamoxifen administration is similar to postnatal results from global $\beta 1 \mathrm{KO}$ mice and beta-cell specific FAK-knockout mice [14, 19]. However, this observation is not in alignment with the RIP $\beta 1 \mathrm{KO}$ study [15], which found normal glucose levels when $\beta 1$ integrin was knocked out in beta-cells at conception. Furthermore, an increase in ECM components vitronectin and laminin-5 $\beta$-chain, which are ligands of $\alpha \mathrm{V} \beta 3$ and $\alpha 6 \beta 4$ respectively, was observed in RIP $\beta 1 \mathrm{KO}$ islets. This result suggests a possible compensatory response during embryonic development and postnatal remodelling that might be responsible for maintained glucose homeostasis. We found a reduction of $\alpha \mathrm{V}$ and $\alpha 6$ integrin mRNA and protein in MIP $\beta 1 \mathrm{KO}$ islets, yet aged MIP $\beta 1 \mathrm{KO}$ mice (25-35 weeks post-tamoxifen) maintained impaired beta-cell function, suggesting that there was no compensatory effect from other integrins after postnatal knockdown of $\beta 1$ integrin.

Examination of the exocytotic proteins involved in insulin secretion showed reduced Vamp2 and Snap25 mRNA and protein levels in male MIP $\beta 1 \mathrm{KO}$ mice, which impairs docking and release of insulin vesicles from beta-cells [20]. It has been shown that focal adhesion remodelling is required for GSIS through FAK-paxillin interactions, which subsequently increase the levels of activated Snap25 [19, 21]. $\beta 1$ integrin is an essential component for focal adhesion formation and its loss appears to alter the insulin exocytotic machinery through impaired downstream focal adhesion signaling. Although no significant changes in Stx1a and Stx3 were found, a reduction in Munc18-1 protein in the beta-cells of MIP $\beta 1 \mathrm{KO}$ mice was observed. Munc18-1 is a syntaxin binding protein that plays a dual role in transporting Stx la to the plasma membrane and regulating SNARE mediated vesicle fusion [22-24]. Furthermore, Pdx-1, a transcription factor required for proper maintenance and function of beta-cells in adult mice [16], showed a marked decrease in mRNA and protein in male MIP $\beta 1 \mathrm{KO}$ mouse islets. Reduced Pdx-1 could contribute to impaired beta-cell function, insufficient insulin production, and the reduction in beta-cell mass that was observed in male MIP $\beta 1 \mathrm{KO}$ mice. Taken together, these observations show that $\beta 1$ integrin in beta-cells is required for maintaining normal physiological levels of exocytotic machinery, which are pivotal in insulin release.

Our study found a significant reduction in the phosphorylation of $\mathrm{FAK}^{\mathrm{Y} 397}$, a key component in transducing 'outside-in' signaling through $\beta 1$ integrin and responsible for activating multiple downstream signaling molecules [14]. One protein downstream of FAK that was reduced in MIP $\beta 1 \mathrm{KO}$ mouse islets was ERK1/2, important in maintaining function and survival of beta-cells and beta-like cells in vitro $[4,9,12,25]$, and beta-cells in vivo $[13,14]$. Activation of ERK has been shown to play a role in not only beta-cell survival, but also in potentially regulating Pdx-1 expression [4, 9, 12, 14] and GSIS through actin remodelling $[21,25]$. FAK has also been shown to mediate insulin signaling through activation of Akt [19]. Similar to RIP $\beta 1 \mathrm{KO}$ mice [15] and the beta-cell specific FAK knockdown mouse line [19], MIP $\beta 1 \mathrm{KO}$ mice also had decreased phosphorylated $\mathrm{Akt}^{\mathrm{S} 473}$. Akin to our previous study [14], a significant reduction in proliferation (cyclin D1) and an increase in apoptosis (c-PARP) were observed in male MIP $\beta 1 \mathrm{KO}$ mice. These findings indicate that $\beta 1$ integrin signals primarily through the FAK/ERK and Akt cascade in vivo to regulate glucose metabolism, beta-cell survival and function.

Male mice with a global $\beta 1 \mathrm{KO}[14,18]$ displayed severely compromised pancreas architecture and beta-cell function compared to their female littermates. Female MIP $\beta 1 \mathrm{KO}$ mice showed no significant impairment in glucose tolerance until 16 weeks post-tamoxifen, demonstrating that there are gender differences in glucose metabolism and an underlying protective factor in female mice. Estrogen administration has been shown to protect mice from beta-cell ablation in streptozotocin and alloxan-induced diabetes by preventing beta-cell apoptosis [26-27]. Despite only seeing a significant change in proliferative and apoptotic markers in male MIP $\beta 1 \mathrm{KO}$ mice, a significant reduction in both alpha- and beta-cell mass was observed in female MIP $\beta 1 \mathrm{KO}$ mice. In a model of diet-induced diabetes, like in the Goto-Kakizaki rat [28], alpha-cell mass can decrease when beta-cells are reduced. The defect in alpha-cell mass could be attributed to a reduced beta-cell population, which subsequently impacts cell-to-cell contact within the islet, along with reduced nutrient secretion and protein secretion important in eliciting normal ECM development in and around the islets.

In summary, this study is the first to utilize a temporal knockout of $\beta 1$ integrin in beta-cells during the postnatal period and demonstrates that diminished $\beta 1$ integrin leads to compromised beta-cell function and survival through decreased FAK/ERK and Akt signaling cascades. Reduced $\beta 1$ integrin also leads to a decrease in SNARE proteins Snap25, Vamp2, and Munc18-1, indicating $\beta 1$ integrin is important for their activation during insulin exocytosis. Understanding how $\beta 1$ integrin maintains postnatal beta-cell insulin 
secretion and survival could aid in the development of tissue engineering strategies for a bioartificial endocrine pancreas, a new strategy for cell-based therapeutic approaches for the treatment of both type 1 and type 2 diabetes.

\section{MATERIALS AND METHODS}

\section{Inducible beta-cell specific $\beta 1$ integrin -deficient mouse model}

B6;129-Itgb1 $1^{\text {tmlEfu/J }} \quad\left(\beta 1^{f l f t}\right)$ and Tg(Ins1-Crel $E R T)^{I L p h i}(M I P-C r e E R T)$ mice were obtained from Jackson Laboratories (Bar Harbor, MA, USA; stock number: 004605) and Dr. Louis Philipson's laboratory (University of Chicago, Chicago, IL, USA) [29], respectively. MIP-CreERT and $\beta 1^{\text {flf }}$ mice were crossed to produce $M I P-C r e E R T^{+/-} ; \beta$ itg $^{f / /+}$ mice, and these mice were mated to establish the tamoxifen inducible $\beta 1$ integrin knockout experimental mouse model. Tamoxifen (Sigma, St. Louis, MO, USA) administration began at 4 weeks of age and was injected intraperitoneally for 3 consecutive days at a dose of $4 \mathrm{mg} / 20 \mathrm{~g}$ bodyweight to all mice used in this study. Mice were genotyped for $\beta 1$ integrin and MIP-CreERT expression using primers listed in Supplementary Table 1. Experimental MIP$\mathrm{CreERT}^{+} ; \beta$ itg $^{f / f l}$ (MIPß1KO) mice are MIP-CreERT positive (268bp) with both $\beta 1$ integrin alleles floxed by LoxP sites ( $\beta$ itg $\left.^{f l f l}, 280 \mathrm{bp}\right)$. MIP-CreERT; $\beta$ itgfl/fl $^{\text {and }}$ $M I P-C r e E R T^{+} ; \beta$ itg $^{+/+}$(Controls) mice are either MIPCreERT negative with both $\beta 1$ integrin alleles floxed or MIP-CreERT positive with wild-type $\beta 1$ integrin alleles $\left(\beta 1 \mathrm{itg}^{+/+}, 160 \mathrm{bp}\right)[30]$. All protocols were approved by the Animal Use Subcommittee at the University of Western Ontario in accordance with the guidelines of the Canadian Council of Animal Care.

\section{Glucose metabolic studies and glucose- stimulated insulin secretion}

Intraperitoneal glucose and insulin tolerance tests (IPGTT and IPITT, respectively) were conducted at 8, 16, and 25-35 weeks post tamoxifen injection in MIP $\beta 1 \mathrm{KO}$ and control mice. For IPGTT, glucose (D-(+)-glucose; dextrose; Sigma-Aldrich Canada Co., Oakville, Ontario, Canada) was administered intraperitoneally at a dose of $2 \mathrm{mg} / \mathrm{g}$ of bodyweight after a 16 hour fast, and blood glucose levels were recorded over a 120 minute duration. Insulin (Humalin, Eli Lilly, Toronto, Ontario, Canada) at $1 \mathrm{U} / \mathrm{kg}$ of body weight was injected intraperitoneally after a 4 hour fast for IPITT. Area under the curve (AUC) was used to quantify glucose or insulin responsiveness using units of $\mathrm{mmol} / \mathrm{L}$ x minute. GSIS tests were performed at 8 and 16 weeks post-tamoxifen, and blood samples were collected via tail vein at baseline insulin levels ( 0 minutes), and at 5 and 35 minutes after glucose loading [14].
For ex vivo GSIS, islets from both MIP $\beta 1 \mathrm{KO}$ and control mice at 8 and 16 week post-tamoxifen were isolated and hand-picked with 10 islets in duplicate per experimental group. Isolated islets were recovered in RPMI 1640 plus 10\% FBS overnight. Islets were incubated for one hour in low - high - low (2mM - $22 \mathrm{mM}$ - 2mM) serum-free glucose media. The stimulation media was collected for insulin release measurements and islets were collected for insulin content analysis [31].

Plasma insulin, basal insulin release, and insulin secretion under glucose-stimulation were measured using the Mouse Ultrasensitive Insulin ELISA (ALPCO®). A static glucose stimulated insulin secretion index was calculated by dividing the insulin output from the high glucose $(22 \mathrm{mM})$ incubation by the insulin output during the low glucose $(2.2 \mathrm{mM})$ incubation [31]. Islet insulin content was measured and expressed as micrograms per milligram of protein [31].

\section{Immunofluorescence and morphometric analyses}

Pancreata from MIP $\beta 1 \mathrm{KO}$ and control mice at 8,16 , or 25-35 weeks post-tamoxifen were fixed in 4\% paraformaldehyde and embedded in paraffin. Pancreatic sections were prepared from the entire length of the pancreas and stained with primary antibodies listed in Supplementary Table 2. Quantitative evaluations of islet number, size, and alpha-cell and beta-cell mass were performed using Image-Pro software (MediaCybernetics, Rockville, MD, USA) [14, 30]. A minimum of 10 islets per pancreas was manually traced from 5 to 6 different mice per experimental group. The percentages of Pdx-1, Nkx6.1, and Ki67 co-localization in insulin ${ }^{+}$ cells were determined by cell counting using double immunofluorescence staining. Islet capillary density and diameter were measured using $\mathrm{PECAM}^{+}$identification, and data are expressed as a percentage $[14,17]$.

\section{RNA extraction and real-time RT-PCR}

RNA was extracted from isolated islets of MIP $\beta 1 \mathrm{KO}$ and control mice using the RNAqueous-4PCR kit (Invitrogen) [16]. Sequences of PCR primers are provided in Supplementary Table 3. Real-time PCR analyses were performed using the iQ SYBR Green Supermix kit (BioRad Laboratories, Mississauga, ON, Canada). Relative levels of gene expression were calculated and normalized to the internal gene $18 \mathrm{~S}$ rRNA, with at least three biological repeats per experimental group [17].

\section{Protein extraction and western blot analysis}

Isolated islets were sonicated and extracted in a Nonidet-P40 lysis buffer (Sigma-Aldrich; St Louis, MO, USA). Proteins were separated via electrophoresis on either a $5 \%, 7.5 \%$, or $10 \%$ sodium dodecyl sulfatepolyacrylamide gel and transferred onto a nitrocellulose 
membrane (Bio-Rad Laboratories, Hercules, CA, USA). Primary antibodies used for detection are listed in Supplementary Table 2. Proteins were detected using ECL TM_Plus Western Blot detecting reagents (PerkinElmer, Wellesley, MA, USA) and imaged using the Versadoc Imaging System (Bio-Rad Laboratories). Image Lab software (Bio-Rad Laboratories) was used to quantify band intensities using densitometry, and data were normalized to total or appropriate loading controls $[17,30,31]$.

\section{Statistical analyses}

Data are expressed as means \pm SEM. Statistical significance was determined using the unpaired student's $t$-test. Differences were considered statistically significant when $p<0.05$.

\section{ACKNOWLEDGMENTS}

The authors sincerely thank Dr. Louis Philipson from University of Chicago, Chicago, IL, USA for providing the MIP-CreER mouse model. We would also like to thank Dr. Bijun Chen and Mr. Phyo Win for their technical assistance and Ms. Amanda Oakie for her critical comments on the manuscript.

\section{CONFLICTS OF INTEREST}

The authors have no conflicts to disclose.

\section{GRANT SUPPORT}

This work was supported by grants from the Natural Sciences \& Engineering Research Council of Canada.

\section{REFERENCES}

1. Barczyk M, Carracedo S, Gullberg, D. Integrins. Cell Tissue Res. 2010; 339: 269-280. doi: 10.1007/s00441-009-0834-6.

2. Brakebusch C, Fässler R. Beta 1 integrin function in vivo: adhesion, migration and more. Cancer Metastasis Rev. 2005; 24: 403-411. doi: 10.1007/s10555-005-5132-5.

3. Kantengwa S, Beatens D, Sadoul K, Buck CA, Halban PA, Rouiller DG. Identification and characterization of $\alpha 3 \beta 1$ on primary and transformed rat islet cells. Exp Cell Res. 1997; 237: 394-402.

4. Saleem S, Li J, Yee SP, Fellows GF, Goodyer CG, Wang R. $\beta 1$-integrin-FAK-ERK signaling pathway is essential for human fetal islet cell differentiation and survival. J Pathol. 2009; 219: 182-192. doi: 10.1002/path.2577.

5. Bosco D, Meda P, Halban PA, Rouiller DG. Importance of cell-matrix interactions in rat islet $\beta$-cell secretion in vitro: role of $\alpha 6 \beta 1$ integrin. Diabetes. 2000; 49: 233-243.
6. Yashpal NK, Li J, Wheeler MB, Wang R. Expression of $\beta 1$-integrin receptors during rat pancreas developmentsites and dynamics. Endocrinology. 2005; 146: 1798-1807. doi: 10.1210/en.2004-1292.

7. Parnaud G, Hammar E, Rouiller DG, Armanet M, Halban PA, Bosco D. Blockade of $\beta 1$ integrin-laminin-5 interaction affects spreading and insulin secretion of rat $\beta$-cells attached on extracellular matrix. Diabetes. 2006; 55: 1413-1420.

8. Hammar E, Parnaud G, Bosco D, Perriraz N, Maedler K, Donath M, Rouiller DG, Halban PA. Extracellular matrix protects pancreatic $\beta$-cells against apoptosis: role of shortand long-term signaling pathways. Diabetes. 2004; 53: 2034-2041.

9. Wang R, Li J, Lyte K, Yashpal NK, Fellows F, Goodyer CG. Role for $\beta 1$ integrin and its associated $\alpha 3, \alpha 5$, and $\alpha 6$ subunits in development of the human fetal pancreas. Diabetes 2005; 54: 2080-2089.

10. Kaido T, Yebra M, Cirulli V, Montgomery AM. Regulation of human $\beta$-cell adhesion, motility, and insulin secretion by collagen IV and its receptor $\alpha 1 \beta 1$. J Biol Chem. 2004; 279 : 53762-53769. doi: 10.1074/jbc.M411202200.

11. Kaido T, Perez B, Yebra M, Hill J, Cirulli V, Hayek A, Montgomery AM. $\alpha \mathrm{v}$-integrin utilization in human $\beta$ cell adhesion, spreading, and motility. J Biol Chem. 2004; 279: 17731-17737. doi: 10.1074/jbc.M308425200.

12. Krishnamurthy M, Li J, Al-Masri M, Wang R. Expression and function of $\alpha \beta 1$-integrins in pancreatic $\beta$ (INS-1) cells. J Cell Commun Signal. 2008; 2: 67-79. doi: 10.1007/ s12079-008-0030-6.

13. Riopel M, Wang R. Collagen matrix supports pancreatic survival and function. Front Biosci (Landmark Ed). 2014; 19:77-90.

14. Riopel M, Krishnamurthy M, Li J, Liu S, Leask A, Wang R. Conditional $\beta 1$-integrin-deficient mice display impaired pancreatic $\beta$-cell function. J Pathol. 2011; 224: 45-55. doi: 10.1002/path.2849.

15. Diaferia GR, Jimenez-Caliani AJ, Ranjitkar P, Yang W, Hardiman G, Rhodes CJ, Crisa L, Cirulli V. $\beta 1$ integrin is a crucial regulator of pancreatic $\beta$-cell expansion. Development. 2013; 140: 3360-3372. doi: 10.1242/ dev.098533.

16. McKinnon CM, Docherty K. Pancreatic duodenal homeobox-1, Pdx-1, a major regulator of beta cell identity and function. Diabetologia. 2001; 44: 1203-1214. doi: 10.1007/s001250100628.

17. Feng ZC, Popell A, Li J, Silverstein J, Oakie A, Yee SP, Wang R. c-Kit receptor signaling regulates islet vasculature, $\beta$-cell survival, and function in vivo. Diabetes. 2015; 64: 3852-3866. doi: 10.2337/db15-0054.

18. Riopel MM, Li J, Liu S, Leask A, Wang R. $\beta 1$ integrinextracellular matrix interactions are essential for maintaining exocrine pancreas architecture and function. Lab Invest. 2013; 93: 31-40. doi: 10.1038/ labinvest.2012.147. 
19. Cai EP, Casimir M, Schroer SA, Luk CT, Shi SY, Choi D, Dai XQ, Hajmrle C, Spigelman AF, Zhu D, Gaisano HY, MacDonald PE, Woo M. In vivo role of focal adhesion kinase in regulating pancreatic beta-cell mass and function through insulin signaling, actin dynamics, and granule trafficking. Diabetes. 2012; 61: 1708-1718. doi: 10.2337/ db11-1344.

20. Thurmond DC, Gonelle-Gispert C, Furukawa M, Halban PA, Pessin JE. Glucose-stimulated insulin secretion is coupled to the interaction of actin with the t-SNARE (target membrane soluble N-ethylmaleimide-sensitive factor attachment protein receptor protein) complex. Mol Endocrinol. 2003; 17: 732-742. doi: 10.1210/me.2002-0333.

21. Rondas D, Tomas A, Halban PA. Focal adhesion remodeling is crucial for glucose-stimulated insulin secretion and involves activation of focal adhesion kinase and paxillin. Diabetes. 2011; 60: 1146-1157. doi: 10.2337/db10-0946.

22. Toonen RF, de Vries KJ, Zalm R, Südhof TC, Verhage M. Munc18-1 stabilizes syntaxin 1, but is not essential for syntaxin 1 targeting and SNARE complex formation. J Neurochem. 2005; 93: 1393-1400. doi: 10.1111/j.1471-4159.2005.03128.x.

23. Dawidowski D, Cafiso DS. Allosteric control of syntaxin 1a by munc18-1: characterization of the open and closed conformations of syntaxin. Biophys J. 2013; 104: 15851594. doi: 10.1016/j.bpj.2013.02.004.

24. Tomas A, Meda P, Regazzi R, Pessin JE, Halban PA. Munc18-1 and granuphilin collaborate during insulin granule exocytosis. Traffic. 2008; 9: 813-832. doi: 10.1111/j.1600-0854.2008.00709.x.

25. Tomas A, Yerman B, Min L, Pessin JE, Halban PA. Regulation of pancreatic beta-cell insulin secretion by actin cytoskeleton remodelling: role of gelsolin and cooperation with the MAPK signaling pathway. J Cell Sci. 2006; 15: 2156-2167. doi: 10.1242/jcs.02942.

26. Le May C, Chu K, Hu M, Ortega CS, Simpson ER, Tsai MJ, Mauvais-Jarvis F. Estrogens protect pancreatic betacells from apoptosis and prevent insulin-deficient diabetes mellitus in mice. Proc Natl Acad Sci USA. 2006; 103: 9232-9237. doi: 10.1073/pnas.0602956103.

27. Kilic G, Alverez-Mercado AI, Zarrouki B, Opland D, Liew CW, Alonso LC, Myers MG Jr, Jonas JC, Poitout $\mathrm{V}$, Kulkarni RN, Mauvais-Jarvis F. The islet estrogen receptor- $\alpha$ is induced by hyperglycemia and protects against oxidative stress-induced insulin-deficient diabetes. PLos One. 2014; 9: e87941. doi: 10.1371/journal.pone.0087941.

28. Movassat J, Saulnier C, Serradas P, Portha B. Impaired development of pancreatic beta-cell mass is a primary event during the progression to diabetes in the GK rat. Diabetologia. 1997; 40: 916-925. doi: 10.1007/ s001250050768.

29. Tamarina NA, Roe MW, Philipson L. Characterization of mice expressing Ins1 gene promoter driven CreERT recombinase for conditional gene deletion in pancreatic $\beta$-cells. Islets. 2014; 6: e27685. doi: 10.4161/isl.27685

30. Trinder M, Zhou L, Oakie A, Riopel M, Wang R. $\beta$-cell insulin receptor deficiency during in utero development induces an islet compensatory overgrowth response. Oncotarget. 2016; 7: 44927-44940. doi: 10.18632/ oncotarget. 10342.

31. Feng ZC, Li J, Turco BA, Riopel M, Yee SP, Wang R. Critical role of c-Kit in beta cell function: increased insulin secretion and protection against diabetes in a mouse model. Diabetologia. 2012; 55: 2214-2225. doi: 10.1007/ s00125-012-2566-5. 